\title{
Editorial
}

\section{Special Issue in Fire Hazards in Energy Systems}

Georgios Boustras*, Centre for Risk, Safety and the Environment (CERISE), European University Cyprus, Egkomi, Cyprus

Guillermo Rein, Imperial College London, London, UK

Serious accidently fires in energy systems like the recent oil train disaster at LacMegantic, the Deepblue Horizon off-shore platform (Fig. 1) or Boeing 787 Dreamliner battery problems, remind us that the ongoing acceleration in energy demand and the new range of technologies being introduced call for an in-depth examination of fire safety engineering in the production, storage and distribution of energy.

This special issue of Fire Technology is devoted to the fire science and technology related to energy systems. The issue wants to contribute to fill the current gaps in the literature that does not provide enough in-depth knowledge on the

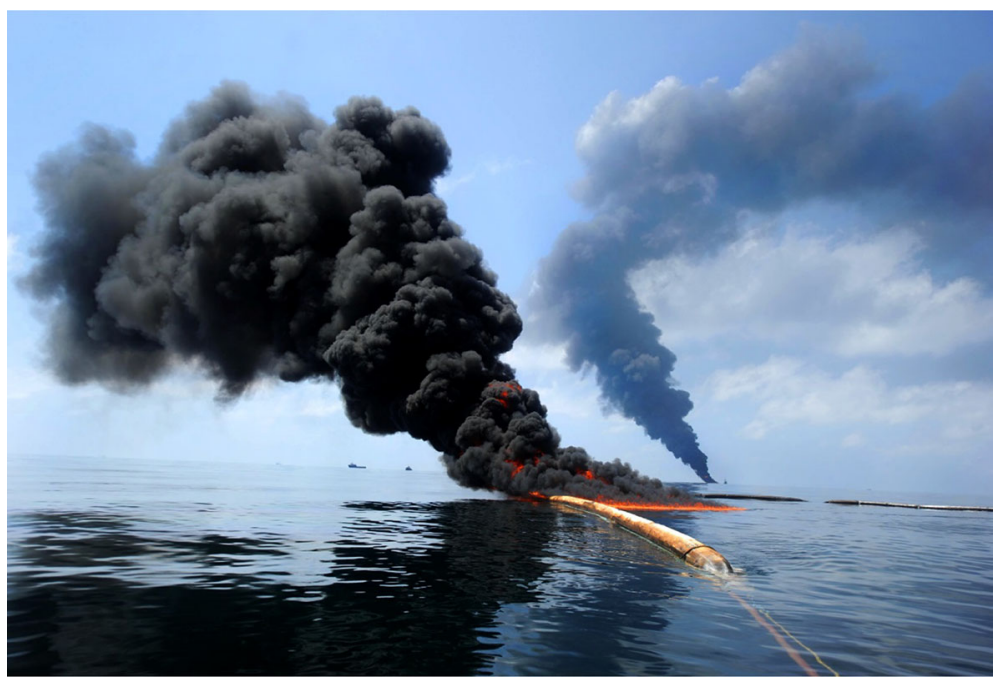

Figure 1. Smoke plumes and fire during controlled burning of the Deepwater Horizon oil spill in the Gulf of Mexico, 2010. Photo by Stumberg, US Navy Public Domain.

\footnotetext{
* Correspondence should be addressed to: Georgios Boustras, E-mail: G.Boustras@euc.ac.cy
} 
safety of many of these systems which are so important and critical to modern society.

Fire Technology has been an outpost of research in the safety of energy systems for decades. Just to name three examples; Nash and Whittle [1] studied in 1978 the firefighting of oil tank fires long before the 2005 Buncefield disaster. Nazarov [2] presented in 1982 on extinguishing fires in oil field; and Rhein [3] showed in 1992 experiments on the extinguishing of Lithium battery fires.

This Issue contains a number of papers covering the fire hazards in a very broad range of energy systems and applications. Hellebuyck et al. [4] present the findings of a study on the fire behavior and performance of mineral oils that are used in electric equipment. Lindstrom and Forsth [5] discuss the design solutions for transformer pit fires. Ma and Larranga [6] study the safe operation of oxycombustion technologies in coal power plants. Cancelliere and Liciotti [7], and Pandian et al. [8] study the various fire hazards caused by photovoltaic solar panels. Chen et al. [9] and Wang et al. [10] present findings on the fire characteristics and suppression of lithium battery fires. Gas storage cylinders and the thermal behavior of their lining is the focus of the papers of Dao et al. [11] and Bustamante et al. [12]. Finally, Worrell and Rochon [13], Beji and Merci [14], and Pretrel et al. [15] quantify risk and model fire scenarios of interest in Nuclear Plant safety.

The Editors are grateful to the authors and reviewers who helped putting this issue together.

\section{References}

1. Nash P, Whittle J (1978) Fighting fires in oil storage tanks using base injection of foam-Part I. Fire Technol 14(1):15-27

2. Nazarov Y (1982) USSR: Putting out fires at oil fields. Fire Technol 18(3):300-301

3. Rhein RA (1992) An experimental study of the use of liquid argon and argon-filled aqueous foams for the extinction of lithium fires. Fire Technol 28(4):290-316

4. Hellebuyck D, van Hees P, Magnusson T, Jörud F, Rosberg D, Janssens M (2015) Fire behaviour of less-combustible dielectric liquids in a nuclear facility. Fire Technol. doi:10.1007/s10694-015-0480-3

5. Lindstrom J, Forsth M (2014) Fire test of profile plank for transformer pit fire protection. Fire Technol. doi:10.1007/s10694-014-0409-2

6. Ma T, Larranga M (2015) Theoretical Flammability Diagrams for Oxy-combustion. Fire Technol. doi:10.1007/s10694-015-0463-4

7. Cancelliere P, Liciotti C (2014) Fire behaviour and performance of photovoltaic module backsheets. Fire Technol. doi:10.1007/s10694-014-0449-7

8. Pandian A, Bansal K, Thiruvadigal DJ, Sakthivel S (2015) Fire hazards and overheating caused by shading faults on photo voltaic solar panel. Fire Technol. doi:10.1007/ s10694-015-0509-7

9. Chen M, He Y, Zhou CD, Richard Y, Wang J (2014) Experimental study on the combustion characteristics of primary lithium batteries fire. Fire Technol. doi:10.1007/ s10694-014-0450-1 
10. Wang Q, Shao G, Duan Q, Chen M, Li Y, Wu K, Liu B, Peng P, Sun J (2015) The efficiency of heptafluoropropane fire extinguishing agent on suppressing the lithium titanate battery fire. Fire Technol. doi:10.1007/s10694-015-0531-9

11. Dao DQ, Luche J, Rogaume T, Richard F, Bustamante-Valencia L, Ruban S (2014) Polyamide 6 and polyurethane used as liner for hydrogen composite cylinder: an estimation of fire behaviours. Fire Technol. doi:10.1007/s10694-014-0423-4

12. Bustamante Valencia L, Blanc-Vannet P, Domergue D, Heudier L, Jamois D (2015) Thermal history resulting in the failure of lightweight fully-wrapped composite pressure vessel for hydrogen in a fire experimental facility. Fire Technol. doi:10.1007/s10694015-0513-y

13. Worrell C, Rochon C (2015) Fire probabilistic risk assessment and its applications in the nuclear power industry. Fire Technol. doi:10.1007/s10694-015-0493-y

14. Beji T, Merci B (2014) Assessment of the burning rate of liquid fuels in confined and mechanically-ventilated compartments using a well-stirred reactor approach. Fire Technol. doi:10.1007/s10694-014-0418-1

15. Pretrel H, Koched A, Audouin L (2015) Doorway flows induced by the combined effects of natural and forced ventilation in case of multi-compartments large-scale fire experiments. Fire Technol. doi:10.1007/s10694-015-0524-8 